\title{
Vaccination Studies against Fowl Pox in Chickens
}

\author{
N. K. Shil, M. S. Rahman, S. Paul ${ }^{1}$, S. Y. Cha $^{2}$, H. K. Jang ${ }^{2}$ and H. J. Song ${ }^{2,+}$ \\ Department of Medicine, Bangladesh Agricultural University Mymensingh, Bangladesh \\ ${ }^{1}$ Department of Medicine and Surgery, Faculty of Veterinary and Animal Science, Sylhet Agricultural University, Bangladesh \\ ${ }^{2}$ Department of Infectious Diseases and Avian Diseases, and Bio-Safety Research Institute, College of Veterinary Medicine, \\ Chonbuk National University, Jeonju 561-756, Korea.
}

\section{닭에서 계두 예방 접종에 관한 연구}

\author{
N. K. Shil · M. S. Rahman ·S. Paul ${ }^{1}$ 차세연 ${ }^{2} \cdot$ 장형관 $^{2}$ · 송희종 ${ }^{2}+$ \\ 방글라대쉬 미멘싱 농업대학교 의학과, ${ }^{1}$ 방글라대쉬 실헷 농업대학교 수의축산학과 내과 및 외과학교실 \\ ${ }^{2}$ 전북대학교 수의과대학 전염병학 및 조류질병학교실, 생체안전성연구소
}

\begin{abstract}
Fayoumi chicks were vaccinated with fowl pox virus vaccine and pigeon pox virus vaccine. The protective potentiality of the two vaccines was compared in field condition in Bangladesh. The percentage of 'take reaction' was assessed to conclude its relationship with better immune response and recorded $93.33 \%$ and $100 \%$ in birds of group B and group C, respectively. The mean passive hemagglutination (PHA) antibody titre after primary vaccination was $32 \pm 14.81$ in group B and $33 \pm 13.66$ in group C. Following booster vaccination, the mean PHA titres level at pre challenge of group B was $46.93 \pm 16.52$ and 55.46 \pm 14.64 in group C. The PHA titre of group B and C at two weeks post challenge recorded 93.86 \pm 33.04 and $110.93 \pm$ 29.29, respectively. PHA titre significantly $(P<0.01)$ increased after vaccination and post challenge compared to pre- vaccination titre. There was significant variation $(\mathrm{p}<0.01)$ of PHA titre at pre challenge in these groups using different vaccine combinations, but all the vaccinated birds resisted challenge infection.
\end{abstract}

(Key words : Fayoumi chicks, fowl and pigeon pox virus vaccine, protective potentiality)

\section{Introduction}

Fowl pox is an economically important viral disease of chicken and turkey. The causative agent belongs to the genus Avipoxvirus under the family Poxviridae. The disease is characterized by discrete nodular proliferative skin lesions on non feathered parts (cuteneous form) or fibrino-necrotic lesions in mucous membranes of upper respiratory tract, mouth, esophagus (diphtheritic form) terminating with the formation of scabs and desquamation of degenerated epithelium (Tripathy and Reed, 1997a). Fowl pox has been considered as an important viral endemic disease in Bangladesh with mortality as high as 60 $70 \%$ with large number of incident per year (Siddiky et al., 2004). In relation to the disease management in the project area of
Smallholder Livestock Development Project (SLDP 2) in five southern district preventive measures are practiced by vaccination, but the incidence of different diseases are likely to be seen. Fowl pox is still the malady of chicken of all ages, sexes and breeds either in organized farms or in backyard poultry farming system in Bangladesh, and the losses cause mild reduction in weight gain and drop of egg production in laying chicken. This loss due to fowl pox has been minimized in chicken by vaccination with fowl pox or pigeon pox vaccines (Skinner et al., 2005) and also practiced in the country. But vaccine type and vaccination schedule, application technique, maternal derived antibody (MDA) in chicks and pathogenecity of the field challenge are the important factors. In this paper humoral immune response in vaccinated chickens and efficacy of pigeon pox

\footnotetext{
† To whom correspondence should be addressed : hjsong@chonbuk.ac.kr
} 
virus vaccine and fowl pox virus vaccine against fowl pox was determined.

\section{Materials and Methods}

\section{Experimental Design}

The field study was carried out in the project area (Ramanandapur, Dagonbhuiyan, Feni) of SLDP 2. 60 Fayoumi chicks were assigned to group $\mathrm{A}$ and $\mathrm{B}$, which were subdivided into 4 groups, and the first three groups were used as replicate groups and the last group served as an unvaccinated control. Birds of group A were primarily vaccinated with pigeon pox virus vaccine at their 3 weeks of age by wing web puncture and boosted with the same vaccine at 9 weeks of age. Fowl pox virus vaccine was used to vaccinate birds of group $B$ using the same method and schedule. Vaccinated birds were observed upto 6 9days for the 'take', the typical lesions of pox at the site where vaccine was applied. Blood was collected for serum at 3 weeks (pre vaccination), 9 weeks (pre booster), 12 weeks (pre challenge), and 14 weeks (post challenge) of age from the five birds of each vaccinated and unvaccinated sub groups. Ten birds of each vaccinated sub group and five from each unvaccinated control were challenged with virulent fowl pox virus at 12 weeks of age at $10^{6} \mathrm{EID}_{50} / 0.1 \mathrm{~mL}$ following feather follicle method as described by Winterfield and Reed (1985). Antibody titre of the collected serum was determined by passive hemagglutination (PHA) test to assess the efficacy of the two vaccines.

\section{Vaccines}

Attenuated freeze dried pigeon pox vaccine and fowl pox vaccine produced by Livestock Research Institute (LRI), Directorate of Livestock Service (DLS), Dhaka, Bangladesh were used for the study.

\section{Fowl Pox Virus}

A reposed local strain of fowl pox virus isolated from field outbreak was used to propagate in 10 12 days embryonated eggs via chorioallantoic membrane (CAM) route for $3 \sim 5$ passage (Reed and Schrader, 1989). The dead embryos within 24 hours of inoculation were discarded, all live and dead embryos upto 5 days were chilled at $4{ }^{\circ} \mathrm{C}$ for 18 hours. The CAM with dis- crete or confluent growth of pocks were selected and processed for further passage. The EID $_{50}$ of the test and challenge virus was calculated following the method of Reed and Muench (1938). Virus suspension was also painted over the scarified thigh area of 3 days old chicks.

\section{Passive Hemaglutination Test}

The test was directed by following the method described by Tripathy et al. (1970b). Antigens (fowl pox virus) were coupled to chemically modified erythrocytes (sheep erythrocyte) and then antigen-coated erythrocytes readily were reacted with specific antibodies for hemagglutination. Briefly $10 \mathrm{~mL}$ of sensitized sheep red blood cells (SRBC) were prepared by mixing $1.5 \mathrm{~mL}$ of $2.5 \%$ suspension of tannic acid treated Cells with $0.5 \mathrm{~mL}$ of 1:10 dilution of fowl pox virus suspension and PBS, and incubated at $37^{\circ} \mathrm{C}$ for 30 min by diluting with $1 \%$ normal rabbit serum diluents.

$50 \mu \mathrm{L}$ of PBS was first poured in each well upto 8th well of horizontal row of microtitre plate. The equal amount of test scrum was added in the 1st well. Two fold dilutions of serum ranging from 1: 2 to 1: 256 were prepared. Then $50 \mu \mathrm{L}$ of $0.5 \%$ fowl pox virus sensitized SRBC was added in each of the eight wells. Proper control in three horizontal rows was also maintained. The plates were kept at room temperature for 4 to 5 hours.

The agglutination results were recorded by deposition of diffuse thin layer of clumping of RBC on the bottom of the well. The end point was determined by observing the highest dilution at which cells were agglutinated.

\section{Results}

\section{Reactivation of Fowl Pox Virus}

Pock lesions on CAM stand for the presence of the virus. Discrete pock lesions along with thickening of CAM were observed after harvesting at 5th day of the inoculation in the embryonated eggs. Characteristic lesion in thigh region of 3 days old chick was observed after infecting with fowl pox virus suspension.

\section{Take Reaction}

Following the vaccination by wing web puncture (WWP) 
'take' reaction was observed characterized by the formation of pimples that became further swollen and turned to nodular form lesion typical of pox, later scab was found over the vaccinated area. The lesion was subsided within 5 10th day of its appearance. No adverse reaction was observed in the birds following the formation of the lesions. The average percentage of 'take' reaction of vaccinated birds of group B and C were 93.33\% and $100.0 \%$, respectively (Table 1 ).

\section{Passive Hemaglutination (PHA) Titre of Sera}

The serum of randomly selected 5 chicks of each subgroup including control were tested at the 3 weeks of age to determine the antibody titre by PHA micro plate test at pre vaccination stage and the average recorded result of PHA titre was $\geq 4 \pm 0$.

At the 9 weeks of age, the mean titre values of birds of subgroup B1, B2 and B3 priming with pigeon pox vaccine re-

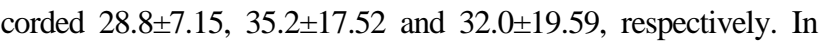
case of subgroup C1, C2 and C3 vaccinated with fowl pox vaccine the mean titre values were $28.8 \pm 7.15,44.8 \pm 17.52$ and 25.6 \pm 8.76 , respectively. The average PHA titre values of group $\mathrm{B}$ and $\mathrm{C}$ recorded were $32.0 \pm 14.81$ and $33.0 \pm 13.66$.

At the 3 weeks of booster vaccination, the recorded PHA titre values of subgroup B1, B2 and B3 vaccinated with pigeon pox vaccine were $44.8 \pm 17.52,51.2 \pm 17.52$ and $44.8 \pm 17.52$, respectively. Subgroup C1, C2 and C3 were vaccinated with fowl pox vaccine as booster and the antibody titre values measured at that period were 57.6 $\pm 14.31,51.2 \pm 17.52$ and $57.6 \pm$ 14.31 , respectively. The average antibody titre values were $46.93 \pm$ 16.52 and $55.46 \pm 14.64$, respectively for the group B and C.

At the second week of post challenge, the PHA titre values were 89.6 \pm 35.06 , 89.6 \pm 35.05 and $102.4 \pm 35.05$ for subgroup B1, B2 and B3, respectively. In case of subgroup C1, C2 and C3 the titre values were $102.4 \pm 35.05,115.2 \pm 28.62$ and $115.2 \pm 28.62$, respectively. The mean highest titre value was $110.93 \pm 29.29$ in group C followed by group B $(93.86 \pm 33.04)$.

\section{Challenge Infection}

Each bird was infected with thigh feather follicle method. A predetermined one chick dose of $0.1 \mathrm{~mL}$ of virulent fowl pox virus having a virus concentration of $10^{6}$ EID $_{50}$ per $0.1 \mathrm{~mL}$ was dosed at the 12 weeks of the age. It was observed that 10 (100.0\%) challenged birds of each vaccinated subgroups of group $\mathrm{B}$ and $\mathrm{C}$ were protected against infection with virulent fowl pox virus where all 5 challenged birds of each control groups could not withstand such exposure.

\section{Discussion}

Pigeon pox vaccine and fowl pox vaccine were used to assess the comparative efficacy against fowl pox. Humoral immune response plays an important role in protecting birds against fowl pox infection (Tripathy and Reed, 1997). The investigation encompassed recording of 'take' reaction on the site of inoculation, measurement of antibody titre by passive hemagglutination test and observing birds' resistance to challenge infection with a virulent field isolates of fowl pox virus.

'Take reaction' characterized by the formation of pimple among vaccinated birds was noted in this study, which was also reported by Tripathy and Reed (1997a). No adverse reaction was observed in vaccinated birds following appearance of 'take' (Sarma and Sharma, 1990). All the vaccinated birds resisted challenge infection with different level of 'take reaction' (Table 1). A lack of ‘take’ reaction doesn't necessarily indicate a lack of immunity (Jordan and Pattison, 1996).

During propagating local strain of fowl pox in 10 12 days

Table 1. Relationship of 'take reaction', titre levels of serum at different vaccination schedule and protection percentage at challenge test

\begin{tabular}{cccccc}
\hline \hline \multirow{2}{*}{ Group } & \multicolumn{5}{c}{ Antibody titres } \\
\cline { 2 - 6 } & Pre booster & Pre challenge $^{*}$ & Post challenge & Take reaction (\%) & Protection (\%) \\
\hline B & $32.0 \pm 14.81$ & $46.93 \pm 16.52$ & $93.86 \pm 33.04$ & 93.33 & 100.0 \\
C & $33.0 \pm 13.66$ & $55.46 \pm 14.64$ & $110.93 \pm 29.29$ & 100.0 & 100.0 \\
\hline
\end{tabular}

\footnotetext{
* Significantly differed at $1 \%$ level.
} 
old embryonated chicken eggs, a discrete pock lesion on CAM was found. It coincides with the finding of Reed and Schrader (1989). Cunningham (1973) noted that single pock lesion found on the CAM was considered to be a positive response for the embryo inoculated with the virus. Three days old chicks exhibited lesions in the scarified denuded follicular area upon infection with the virus suspension.

Followed by the primary and booster vaccination, the PHA titre values of group $\mathrm{C}$ were more than group $\mathrm{B}$, this may be due to fowl pox vaccine produced solid and durable immunity (Tripathy and Reed, 1997a). In the present study, the recorded antibody titre values at different stage by PHA micro plate method were more than the findings of previous study. The result might be caused by the use of different vaccine virus strain, vaccination method, age and strain of challenge virus (Sarma and Sharma, 1990). The PHA titre value was increased following primary vaccination which again reached a significance level $(P<$ 0.01 ) after booster vaccination and challenge (Table 1 ). The rise in antibody titre in challenged birds was suggestive of active immune response of the vaccinated birds. These results obtained herein correspond to the result of Prabhakar et al (1981).

Significant variation $(P<0.01)$ was found among the groups $\mathrm{B}$ and $\mathrm{C}$ in regard to immune response at prechallenge level using different vaccines, but no significant variation was found in case of protection in these groups. This might be due to both cell mediated and humoral immunity play a critical role in the protection against fowl pox virus and individual birds' capacity to fight field infection. Siddique et al (1997) also stated the same critiques.

\section{Acknowldgement}

Authors acknowledge the Dr. N. C. Debnath, Honorable Vice Chancellor, Chittagong Veterinary and Animal Science University, and financial support of Smallholder Livestock Development Project 2 (a DANIDA aided project).

\section{적 요}

파유미 종 닭에 계두 및 구두 백신을 접종하고 2종의 백
신에 대한 방어 능력을 방글라대쉬의 야외의 닭 사육 조건 에서 비교하였다. 'Take reaction'의 수율을 평가하여 이것을 더 나은 면역 반응과 관련지어 해석하였으며, 그룹 $\mathrm{B}$ 와 그룹 $\mathrm{C}$ 의 닭은 각각 $93.33 \%$ 와 $100 \%$ 의 면역 반응을 보여주었다. 1 차 예방접종에 따른 평균 $\mathrm{PHA}$ 항체가는 $\mathrm{B}$ 와 $\mathrm{C}$ 그룹에서 각각 $32 \pm 14.81$ 과 $33 \pm 13.66$ 으로 나타났다.

보강 접종 후 평균 $\mathrm{PHA}$ 항체가는 $\mathrm{B}$ 및 $\mathrm{C}$ 그룹의 전 처리 군에서는 $46.93 \pm 16.52$ 와 $55.46 \pm 14.64$ 이었으며, 공격접종 2주 후 시점에서 향체가는 각각 93.86 \pm 33.04 와 $110.93 \pm 29.29$ 로 나타났다. PHA 항체가는 백신 접종 후와 접종 후 처치군들 에서 백신접종 전 항체가에 비해 현저하게 증가함을 보여주 었다. 이렇게 현저한 PHA 항체가의 차이는 사용한 백신의 종류가 다양함으로 인해 발생되는 것이기도 하였으나, 백신 접종을 받은 모든 닭들은 감염에 대한 저항력을 보여주었다.

색인어: 파유미 종 닭, 계두 및 구두 백신, 방어 능력 비교

\section{References}

Cunningham CH 1973 A laboratory guide in virology. 7th Edition. Burgess, Minneapolis.

Jordan FTW, Pattison M 1996 Poultry diseases. 4th Edition. WB Saunders Company Ltd. London.

Prabhakar TG, Padmanaban VD, Balaprkasam RA 1981 Immune response to fowl pox vaccination. Ibid 11:83.

Reed JL, Muench H 1938 A simple method of estimating fifty percent end point. Am J Hygiene 27:493.

Reed WM, Schrader DL 1989 Pathogenicity and immunogenicity of mynah pox virus in chickens and bobwhite quail. Poult Sci 68(5):361-638.

Sarma DK, Sharma SN 1990 Immunization of chicks with fowl pox virus vaccines by intramuscular route. Indian J Anim Sci 60(1):1-5.

Siddiky MNA, Amin MM, Amin MA, Suman MSR 2004 Efficacy of experimentally developed pigeon pox vaccine against fowl pox. Bangladesh Vet 21(2):92-96.

Siddique AB, Rahman MB, Amin MM, Rahman MM 1997 Antibody titres in chicks following pigeon pox virus inoculation. Bangladesh Vet 14(1-2):12-14.

Skinner MA, Laidlaw SM, Eldaghayes I, Kaiser P, Cottingham MG 2005 Fowl pox virus as a recombinant vaccine vector for use in mammals and poultry. Expert Rev Vaccines 4(1): 
63-76.

Tripathy DN, Hanson LE, Myers WL 1970b Passive hemagglutination with fowl pox virus. Avian Dis 14:29-38.

Tripathy DN, Reed WM 1997a Diseases of poultry. 10th Edi- tion, Iowa State University Press, Ames, Iowa, USA.

Winterfield RW, Reed W 1985 Avian pox: Infection and immunity with quail, psittacine, fowl, and pigeon pox viruses. Poult Sci 64(1):65-70. 